\title{
Efficacy of Dietary Urea-Impregnated Zeolite in Improving Rumen Fermentation Characteristics of Local Lamb
}

\author{
D. Kardaya*, D. Sudrajat, \& E. Dihansih \\ Department of Animal Sciences, Faculty of Agribusiness and Food Technology, Djuanda University, Bogor \\ PO Box 35, Bogor 16720, Indonesia \\ (Received 29-10-2012; Reviewed 26-12-2012; Accepted 15-01-2013)
}

\begin{abstract}
A research on dietary inclusion of urea-impregnated zeolite as slow-release urea (SRU) agent had been conducted to reveal its effect on ruminal fermentation characteristics in local lambs. The research used 24 heads of 7-8 mo old of local male lambs with $(20.12 \pm 2.1 \mathrm{~kg} \mathrm{BW})$ designed upon a randomized block design. Treatments consisted of diets contained no urea, urea, zeolite, and urea-impregnated zeolite. The collected data was analyzed with UNIANOVA and Duncan's multiple-range test. Results indicated that feeding no urea, zeolite, or urea-impregnated zeolite ration produced lower ruminal ammonia nitrogen than feeding urea ration $(\mathrm{P}<0.05)$. Feeding zeolite ration produced lower ruminal $\mathrm{pH}$ than feeding urea ration $(\mathrm{P}<0.05)$. Despite total VFAs were similar across the treatments, feeding urea-impregnated zeolite ration produced lower ruminal acetate, acetate to propionate ratio, or methane production than feeding urea ration $(\mathrm{P}<0.05)$. Feeding urea ration produced the lowest molar proportion of branch-chained VFAs $(\mathrm{P}<0.05)$. Feeding urea ration produced higher plasma urea concentration than feeding no urea ration $(2.75 \mathrm{mM}$ vs. $2.16 \mathrm{mM} ; \mathrm{P}<0.05)$. In conclusion, zeolite or urea-impregnated zeolite as slow-release ammonia or SRU agent was potential in decreasing ruminal ammonia, $\mathrm{pH}$, acetate to propionate ratio, methane, and maintaining low plasma urea within its physiological range.
\end{abstract}

Key words: rumen ammonia, lamb, urea-impregnated zeolite, VFA, slow-release urea

\section{ABSTRAK}

Penelitian zeolit-urea sebagai bahan urea lepas-lamban dalam ransum dilakukan untuk mengungkap pengaruhnya terhadap karakteristik fermentasi rumen pada domba muda. Penelitian menggunakan 24 ekor domba jantan muda umur 7-8 bulan, berbobot 20,12 $\pm 2,1 \mathrm{~kg}$ yang dirancang berdasarkan rancangan acak kelompok. Perlakuan terdiri atas ransum tanpa urea, berurea, berzeolit, dan berzeolit-urea. Data yang berhasil dihimpun, dianalisis dengan sidik ragam dan uji jarak ganda Duncan. Hasil penelitian mengungkapkan pemberian ransum tanpa urea, berzeolit, atau berzeoliturea menghasilkan $\mathrm{N}$-amonia rumen yang lebih rendah daripada pemberian ransum berurea $(\mathrm{P}<0,05)$. Pemberian ransum berzeolit memperlihatkan $\mathrm{pH}$ rumen lebih rendah daripada pemberian ransum berurea $(P<0,05)$. Meskipun total VFA sama antarperlakuan $(P>0,05)$, namun pemberian ransum berzeolit-urea menghasilkan asetat, nisbah asetat:propionat, dan produksi gas metan rumen domba yang lebih rendah daripada pemberian ransum berurea $(P<0,05)$. Pemberian ransum berurea menghasilkan proporsi molar asam lemak berantai cabang (BCVFA) terendah $(\mathbf{P}<0,05)$. Kadar urea plasma domba yang diberi ransum berurea lebih tinggi daripada domba yang diberi ransum tanpa urea $(2,75 \mathrm{mM}$ vs. $2,16 \mathrm{mM} ; \mathrm{P}<0,05)$. Disimpulkan, zeolit atau zeolite-urea sebagai bahan ammonia atau urea lepas-lamban dalam sistem fermentasi rumen mampu menurunkan kadar amonia, nisbah asetat:propionat, produksi gas metan, dan $\mathrm{pH}$ rumen, serta mempertahankan kadar urea plasma tetap dalam kisaran fisiologis normal.

Kata kunci: amonia rumen, domba muda, zeolit, VFA rumen, urea lepas-lamban

\footnotetext{
*Corresponding author:

Phone: +62-812-9488-226,

E-mail: dede.kardaya@unida.ac.id; $\underline{\text { dkardaya@gmail.com }}$
} 


\section{INTRODUCTION}

Urea is the most frequently used for substituting natural feed protein in ruminant rations. However, because it is readily hydrolyzed to ammonia and absorbed into circulatory system, urea may contribute negative impact on ruminant animals. Numerous efforts to reduce hydrolysis rate of ammonia from urea, for example, were urease inhibitors such as zinc compounds (Kardaya et al., 2000), polymer coated urea (Taylor-Edwards et al., 2009), and calcium-urea compound (Golombeski et al., 2006). In addition, Migliorati et al. (2007) used zeolite to sink ammonium ion in rumen fluids based on its cation exchange capacity. In previous study, Kardaya et al. (2009) used dietary zinc-urea complex, urea-impregnated zeolite, and zinc-urea-impregnated zeolite complex to make slower ammonia release from urea on in vitro study and revealed that each of the three products showed slow-release urea (SRU) characteristics under different molasses levels as readily available carbohydrate sources. This in vitro study, however, ignored absorption of fermentation metabolites that naturally occurs under in vivo study. Therefore, present research aimed to reveal effects of dietary inclusion of urea-impregnated zeolite as slowrelease urea agent on rumen fermentation characteristics and plasma metabolites of lambs.

\section{MATERIALS AND METHODS}

\section{Animals and Diets}

Twenty four of seven to eight months old male lambs with $20.12 \pm 2.1 \mathrm{~kg}$ of initial BW were used in a randomized block design experiment with four dietary treatments and six groups of initial BW to reveal rumen fermentation characteristics the lamb in feedlot. Lambs were randomly allocated to one of four dietary treatments for each the initial BW groups, housed in 24 individual pens with one lamb per pen $\left(0.7 \mathrm{~m}^{2}\right)$. The four dietary treatments (Table 1) consisted of $60 \%$ of field grass and $40 \%$ of concentrates (DM basis) contained no urea $(\mathrm{NU})$, urea $(\mathrm{U})$, zeolite $(\mathrm{Z})$, or urea-impregnated zeolite (UZ). The last treatment was considered as SRU products that had been previously used in in vitro study (Kardaya et al., 2009). All the diets were formulated to have similar CP $(16 \%)$, in which proportion of urea in a given rations was $2 \%$ of total concentrate and substituted for $16 \%$ of total natural feed protein whereas ureaimpregnated zeolite was $5 \%$ of total concentrate and represented $16 \%$ of total natural feed protein.

All lambs were treated with albendazole $100 \mathrm{mg}$ $(7.5 \mathrm{mg} / \mathrm{kg} \mathrm{BW})$ at the beginning of the experiment in order for eliminating worm infection. The experimental period was 11 days $(10 \mathrm{~d}$ for diet adaptation and one day for rumen fluid and plasma sampling). The ten-day diet adaptation period was provided for allowing well adaptation and preventing from urea toxicity for the lambs those would be treated with urea ration. Experimental diets were offered twice daily (08:00 and 16:00 h) at 3\% of BW (DM basis) whereas fresh water was available ad libitum.

\section{Rumen Fluid Sampling and Laboratory Analysis}

Rumen fluid was obtained from each lamb by aspiration through a stomach tube at day 11 of experimental period. Each sample (approximately $50 \mathrm{ml}$ ) was taken $4 \mathrm{~h}$ postprandial, filtered through four layers of cheesecloth and ruminal $\mathrm{pH}$ was measured immediately with a digital $\mathrm{pH}$ meter (Accumet Basic pH Meter, Fisher Scientific, Pittsburgh, PA). Samples of filtered ruminal fluid were centrifuged at 3,000 rpm for $15 \mathrm{~min}$ and a two-ml of supernatants were sub sampled into eppendorf tubes and recentrifuged at $15,000 \mathrm{rpm}$ at $-4{ }^{\circ} \mathrm{C}$ for 30 min. Thereafter, ammonia and VFA determination were made on the recentrifuged supernatants. Ruminal ammonia concentration was determined with spectrophotometer (Beckman DU 64, Beckman Instruments, Fullerton, CA) at $630 \mathrm{~nm}$ according to procedure of Broderick and Kang (1980). Ruminal individual VFA concentration was determined with gas chromatography (Model 5890, Hewlett-Packard, Avondale, PA). Ruminal methane production was derived from the individual

Table 1. Feed composition (\%) and nutrient contents (\% DM) of local lamb rations

\begin{tabular}{lcccc}
\hline \multirow{2}{*}{ Components } & \multicolumn{4}{c}{ Ration (DM basis) } \\
\cline { 2 - 5 } & $\mathrm{NU}$ & $\mathrm{U}$ & $\mathrm{Z}$ & $\mathrm{UZ}$ \\
\hline Field grass & 60.00 & 60.00 & 60.00 & 60.00 \\
Pollard & 18.00 & 12.20 & 10.00 & 3.60 \\
Yellow corn & 2.00 & 11.00 & 6.00 & 16.00 \\
Soybean meal & 10.00 & 6.00 & 11.50 & 8.50 \\
Coconut meal & 10.00 & 9.00 & 11.50 & 8.79 \\
Molasses & - & 1.00 & - & 1.00 \\
Zeolite & - & - & 1.00 & - \\
Urea & - & 0.80 & - & - \\
Urea-impregnated & - & - & - & 2.11 \\
zeolite & & & & \\
Nutrient contents: & & & & \\
DM & 65.13 & 64.52 & 65.12 & 64.92 \\
NDF & 52.55 & 49.82 & 51.61 & 48.36 \\
ADF & 28.04 & 27.35 & 27.74 & 29.29 \\
Hemicellulose & 24.51 & 22.47 & 23.87 & 19.07 \\
Cellulose & 21.17 & 20.56 & 20.33 & 21.03 \\
Lignin & 5.38 & 5.39 & 5.03 & 6.18 \\
Ash & 7.70 & 7.31 & 8.33 & 8.24 \\
OM & 92.30 & 92.69 & 91.67 & 91.76 \\
CP & 16.41 & 16.53 & 16.49 & 16.12 \\
CF & 16.80 & 16.21 & 16.82 & 15.80 \\
EE & 3.07 & 3.12 & 3.48 & 2.66 \\
NFE & 56.9 & 56.82 & 55.18 & 58.63 \\
\hline
\end{tabular}

Note: NU: no urea, U: urea Z: zeolite, UZ: urea-impregnated zeolite, urea $\mathrm{N}$ represents $16 \%$ of total natural feed protein $(\mathrm{N} \times 6.25)$. DM: dry matter, NDF: neutral detergent fiber, ADF: acid detergent fiber, OM: organic matter, CP: crude protein, CF: crude fiber, EE: ether extract, NFE: nitrogen free extract. 
VFAs according to the following expression $M=0.5 a$ $-0.25 p+0.5 b$, where $a, p$, and $b$ are moles of acetic, propionic, and butyric acids respectively (Orskov \& Ryle, 1990).

\section{Plasma Sampling and Laboratory Analysis}

Blood was sampled from jugular vein following rumen fluid sampling. Plasma sample were collected through coccygeal venipuncture (7-mL tubes with EDTA; Corvac, Sherwood Medical, St. Louis, MO), inverted for complete mixture with EDTA, plasma $\mathrm{pH}$ was measured immediately with a digital $\mathrm{pH}$ meter (Accumet Basic $\mathrm{pH}$ Meter, Fisher Scientific, Pittsburgh, PA), and in turn, the blood samples were placed on ice before being transported to the laboratory for centrifugation at 1,500 rpm for 25 min. Plasma urea was determined using a commercial assay kits (Sigma procedure no. 640, Sigma Diagnostics).

\section{Statistical Analysis}

All collected data were analyzed as a univariate analyses of variance (UNIANOVA) under a randomized block design and if applicable, Duncan's Multiple Range Test was applied to repeal statistical different among treatment (Steel \& Torrie, 1980). The treatment different was considered to be significant when $\mathrm{P}<0.05$.

\section{RESULTS AND DISCUSSION}

Experimental ration affected $(\mathrm{P}<0.05)$ on ruminal $\mathrm{pH}$-value, ammonia, acetate $\left(\mathrm{C}_{2}\right)$, normal valerate $\left(\mathrm{nC}_{5}\right)$ and acetate/propionate ratio, but not total VFA or other rumen fermentative products (propionate and butyrate) in four hours postprandial (Table 2). Zeolite treatment resulted in lower ruminal $\mathrm{pH}$-value $(\mathrm{P}<0.05)$ compared to urea treatment but showed similar $\mathrm{pH}$-value $(\mathrm{P}>0.05)$ to no urea or urea-impregnated zeolite. Among treatments, urea resulted in the highest ammonia level $(\mathrm{P}<0.05)$ while no urea, zeolite, or urea-impregnated zeolite showed similar ammonia level for each other $(\mathrm{P}>0.05)$. Urea-impregnated zeolite treatment produced lower acetate than urea treatment $(\mathrm{P}<0.05)$, lower $\mathrm{nC}_{5}$ than no urea treatment $(\mathrm{P}<0.05)$, and lower acetate/propionate ratio than urea treatment $(\mathrm{P}<0.05)$. All treatments did not affect significantly on individual VFA when each individual VFA was evaluated under its proportion to total VFA (mM individual VFA/100 mM total VFA) except for BCVFA molar proportion where urea treatment produced the lowest BCVFA molar proportion $(\mathrm{P}<0.05)$ across the treatments. The treatments influenced plasma

Table 2. Rumen fermentation characteristics of lambs fed experimental rations

\begin{tabular}{|c|c|c|c|c|c|c|}
\hline \multirow{2}{*}{ Ruminal parameters } & \multicolumn{4}{|c|}{ Experimental rations } & \multirow{2}{*}{ Mean } & \multirow{2}{*}{$\mathrm{SDM}^{2)}$} \\
\hline & NU & $\mathrm{U}$ & $\mathrm{Z}$ & $\mathrm{UZ}$ & & \\
\hline $\mathrm{pH}$ & $6.67^{\mathrm{ab}}$ & $6.92^{\mathrm{a}}$ & $6.50^{\mathrm{b}}$ & $6.75^{\mathrm{ab}}$ & 6.71 & 0.33 \\
\hline $\mathrm{NH}_{3}, \mathrm{mM}$ & $12.17^{a}$ & $15.00^{\mathrm{b}}$ & $12.33^{\mathrm{a}}$ & $11.50^{\mathrm{a}}$ & 12.75 & 1.89 \\
\hline VFA, mM & 134.36 & 139.26 & 129.60 & 98.53 & 125.44 & 37.35 \\
\hline Acetate (C2) & $89.03^{\mathrm{ab}}$ & $98.72^{\mathrm{a}}$ & $89.00^{\mathrm{ab}}$ & $62.43^{\mathrm{b}}$ & 84.79 & 28.68 \\
\hline Propionate (C3) & 27.49 & 23.02 & 24.49 & 20.86 & 23.96 & 7.22 \\
\hline Butyrate (C4) & 15.74 & 15.97 & 14.40 & 13.91 & 15.01 & 5.71 \\
\hline Iso-butyrate (iC4) & 1.31 & 0.94 & 1.26 & 0.94 & 1.11 & 0.37 \\
\hline Normal-butyrate (nC4) & 14.43 & 15.03 & 13.15 & 12.97 & 13.89 & 5.43 \\
\hline Valerate C5) & 2.10 & 1.55 & 1.71 & 1.33 & 1.67 & 0.82 \\
\hline Iso-valerate (iC5) & 1.03 & 0.81 & 0.87 & 0.85 & 0.89 & 0.39 \\
\hline Normal-valerate (nC5) & $1.08^{\mathrm{a}}$ & $0.74^{\mathrm{ab}}$ & $0.84^{\mathrm{ab}}$ & $0.48^{\mathrm{b}}$ & 0.78 & 0.51 \\
\hline BCVFA & 2.34 & 1.75 & 2.12 & 1.79 & 2.00 & 0.69 \\
\hline C2:C3 ratio & $3.25^{\mathrm{ab}}$ & $4.65^{\mathrm{a}}$ & $3.74^{\mathrm{ab}}$ & $3.04^{\mathrm{b}}$ & 3.67 & 1.37 \\
\hline \multicolumn{7}{|l|}{ VFA proportion, mM/100 mM: } \\
\hline $\mathrm{C} 2$ & 66.00 & 70.59 & 67.63 & 64.14 & 67.09 & 5.33 \\
\hline $\mathrm{C} 3$ & 20.62 & 16.75 & 19.59 & 21.44 & 19.60 & 3.83 \\
\hline $\mathrm{C} 4$ & 11.81 & 11.55 & 11.36 & 13.31 & 12.01 & 2.34 \\
\hline $\mathrm{C} 5$ & 1.58 & 1.10 & 1.43 & 1.11 & 1.30 & 0.39 \\
\hline BCVFA & $1.74^{\mathrm{a}}$ & $1.29^{\mathrm{b}}$ & $1.76^{\mathrm{a}}$ & $1.75^{\mathrm{a}}$ & 1.63 & 0.43 \\
\hline $\mathrm{NH}_{3}:$ VFA ratio & 0.09 & 0.12 & 0.10 & 0.14 & 0.11 & 0.04 \\
\hline Methane $^{3)}, \mathrm{mM}$ & $45.51^{\mathrm{ab}}$ & $51.59^{\mathrm{a}}$ & $45.58^{\mathrm{ab}}$ & $32.96^{b}$ & 43.91 & 15.11 \\
\hline
\end{tabular}

Note: Means in in the same row with different superscripts differ significantly $(\mathrm{P}<0.05) ;{ }^{1)} \mathrm{NU}$ : no urea; U: urea; ZU: zinc-urea; UIZ: urea-impregnated zeolite; ZUZ: zinc-urea-impregnated zeolite. ${ }^{2}$ SDM: standard deviation of means. ${ }^{3}$ Estimated as $\mathrm{CH}_{4}(\mathrm{mM})=0.5$ acetate -0.25 propionate +0.5 butyrate (Orskov \& Ryle, 1990). BCVFA: branch-chained volatile fatty acid. 
urea concentration significantly $(\mathrm{P}<0.05)$ where feeding urea ration produced higher plasma urea concentration than feeding no urea ration.

\section{Ruminal pH Value}

All ruminal $\mathrm{pH}$ value in present research were in range of normal ruminal $\mathrm{pH}$, i.e. 6 to 7 , where ammonia would be present in the form of $\mathrm{NH}_{4}^{+}$as reported by Abdoun et al. (2007). Lower ruminal $\mathrm{pH}$ value as result of zeolite treatment compared to urea treatment (Table 2) indicated that zeolite was able to sink ammonia through its cation exchange capacity. In contrarily, higher ruminal $\mathrm{pH}$ of lambs fed urea ration was because of its higher ruminal ammonia as a result of rapid urea hydrolysis in the rumen. The increase in ruminal $\mathrm{pH}$ as a result of the increase in ruminal ammonia nitrogen was also demonstrated by Pan et al. (2003). According to Mumpton (1999), zeolite, as a cation exchanger, was able to exchange ammonium ion $\left(\mathrm{NH}_{4}^{+}\right)$resulted from decomposition of non-protein nitrogen compound and retained it until many hours before it was released by sodium ion $\left(\mathrm{Na}^{+}\right)$contained in saliva which was entering rumen. Thus, it is reasonable that ruminal $\mathrm{pH}$ value is lower on lambs fed zeolite ration because ruminal ammonia concentration as one of ruminal factors that able to increase ruminal $\mathrm{pH}$ value is decreased by cation exchange capacity of zeolite.

In addition, Mlay et al. (2003) reported that effect of urea on $\mathrm{pH}$ value of rumen fluid increased the $\mathrm{pH}$ value because of its alkalinity or decreased the $\mathrm{pH}$ value because of its better fermentability and its impact on VFA production. Kim et al. (2007), however, suggested that the increase in $\mathrm{pH}$ value of rumen fluid was more as a reflection of the increase in $\mathrm{NH}_{3}$ to VFA ratio. In present research, higher ruminal ammonia $\left(\mathrm{NH}_{3}\right)$ concentration in rumen fluid increased $\mathrm{pH}$ value as it was shown by urea treatment and contrarily, lower ruminal ammonia concentration in rumen fluid decreased ruminal $\mathrm{pH}$ value as it was shown by zeolite treatment (Table 2). In relation to ammonia to VFA ratio, however, ruminal $\mathrm{pH}$ value does not completely figure a reflection of ammonia to VFA ratio as suggested by Kim et al. (2007). All ammonia to VFA ratio values in present research fail to follow significance pattern of the ruminal $\mathrm{pH}$ values. Presumably, ammonia alkalinity rather than its impact on VFA production results in stronger effect on creating $\mathrm{pH}$ value of rumen fluid of lambs fed urea or zeolite ration. As previously stated by Mlay et al. (2003) that $\mathrm{pH}$ value of rumen fluid might increase or decrease depending on effect of urea on its alkalinity, better fermentability, and its impact on VFA production. Even though lambs fed zeolite ration produced lower ruminal $\mathrm{pH}$ those fed urea ration, the ruminal $\mathrm{pH}$ range (6.50 to 6.92) fall within the $\mathrm{pH}$ range for optimal microbial activity, i.e. 6.2 to 7.12 as mentioned by Van Soest (1994).

\section{Ruminal Ammonia}

Ruminal ammonia concentration resulted in present research varied from 11.50 to $15.00 \mathrm{mM}$ (equivalent with 161 to $210 \mathrm{mg}$ ammonia N/L) and fallen within ruminal ammonia $\mathrm{N}$ range (12.48 to $18.28 \mathrm{mM}$, with optimal level of $13.78 \mathrm{mM}$ ) of young rams fed rations contained different level of hydrolyzed feather meal as reported by Puastuti and Mathius (2008). Moreover, Abubakar et al. (2010) reported higher ruminal ammonia N concentrations, i.e. in range of 21.5 to $37.5 \mathrm{mg} / 100 \mathrm{ml}$ (about 15.36 to $26.79 \mathrm{mM}$ ) resulted from sheep fed rations contained different nitrogen sources. More recently, Syahrir et al. (2012) used dietary inclusion of $\mathrm{Ca}(\text { Urea })_{4} \mathrm{Cl}_{2}$ as slowrelease urea agent, recorded no significant different in ruminal ammonia in Ongole grade cattle fed rations contained $1,0.5$, and $0 \%$ of $\mathrm{Ca}(\text { Urea })_{4} \mathrm{Cl}_{2}$ associated with ruminal ammonia concentration of 19.22, 19.66, and $19.37 \mathrm{mM}$, respectively. Apparently, optimal level of ruminal ammonia $\mathrm{N}$ could not be generalized within a certain value or even within a certain range of values because many factors, such as nitrogen sources and other rumen factors influenced the ruminal ammonia $\mathrm{N}$ concentration.

In the present research, lambs fed urea ration produce the highest ruminal ammonia concentration $(\mathrm{P}<0.05)$ while lambs fed no urea, zeolite, or urea-impregnated zeolite ration produce similar low ruminal ammonia concentration, respectively (Table 2). The highest ruminal ammonia concentration of lambs fed urea ration indicate that urea is readily hydrolyzed to ammonia. However, it is very probably that hydrolysis of urea into ammonia become slower when urea is impregnated into zeolite as revealed from lower ruminal ammonia concentration $(11.50 \mathrm{mM})$ in lambs fed urea-impregnated zeolite rations. This result is in agreement with previous research (Kardaya et al., 2009) where urea-impregnated zeolite treatment suppressed ammonia concentration of rumen fluid under in vitro study. It is plausible that the lower ruminal ammonia concentration in lambs fed urea-impregnated zeolite because urea molecules trapped physically in porous material of zeolite led to less accessible for rumen microbial ureases before the urea molecules solubilizing in ruminal fluid, thus requiring more time for the rumen microbial ureases to hydrolyze urea in liquid phases. It is also almost certainly that solid particles of urea while its blend to zeolite particles require more time to become soluble in rumen fluid, thus delay access time of microbial ureases in hydrolyzing urea molecules and led to lower ruminal ammonia concentration. Lower concentration of ruminal ammonia in lambs fed ration contained urea-impregnated zeolite as slow-release urea agent when compared to urea ration in present research also occurred in previous different type of SRU agents such polymer-coated urea (Taylor-Edwards et al., 2009) and calcium-urea (Huntington et al., 2006). It is implicated that urea impregnated-zeolite showed a consistent efficacy as a slow-release urea agent in improving ammonia concentration in rumen fluid.

Lambs fed zeolite ration even resulted in lower ammonia concentration than those fed urea rations $(\mathrm{P}<0.05)$, it does not mean that zeolite has similar efficacy to urea-impregnated zeolite treatment in improving ammonia concentration state in rumen fluid of local lamb because the zeolite ration does not contain urea supplement (Table 1). Thus, it is more valuable when zeolite 
treatment is compared to no urea treatment. In this case, zeolite treatment shows similar ammonia concentration to no urea treatment. It means that efficacy of zeolite in suppressing ammonia concentration does not appear when the ration contains no urea supplement.

\section{Ruminal Volatile Fatty Acids}

Total volatile fatty acids (VFAs) concentration in the present research ranged from 98.53 to $139.26 \mathrm{mM}$. The range fallen in lower limit of normal range (122.5 to $190.3 \mathrm{mM}$ ) if VFAs values of Puastuti et al. (2012) were applied. While concentration of total VFAs did not show any change significantly across all treatments $(\mathrm{P}>0.05)$, its individual VFAs, i.e. acetate $\left(\mathrm{C}_{2}\right)$ and normal valerate $\left(\mathrm{nC}_{5}\right)$ were significantly influenced by the treatment $(\mathrm{P}<0.05$, Table 2$)$. Acetate concentration of rumen fluid in lambs fed no urea treatment was in similar level to the lambs fed other rations $(P>0.05)$ but the lambs fed urea ration showed higher acetate concentration than those fed urea-impregnated zeolite ration $(\mathrm{P}<0.05)$. Normal valerate concentration of rumen fluid was lower in lambs fed urea-impregnated zeolite ration than those fed no urea ration $(\mathrm{P}<0.05)$. Higher acetate concentration in lambs fed urea ration associates to its higher ammonia concentration and its higher $\mathrm{pH}$ value. This finding is fairly in agreement with Pan et al. (2003) who revealed that increase in ruminal ammonia $\mathrm{N}$ might increase ruminal $\mathrm{pH}$, total VFAs and stimulated cellulolytic bacteria activity in the rumen.

Acetate to propionate $\left(\mathrm{C}_{2}: \mathrm{C}_{3}\right)$ ratio was lower in lambs fed urea-impregnated zeolite ration than those fed urea ration $(\mathrm{P}<0.05)$. Apparently, lower acetate concentration in lambs fed urea-impregnated zeolite ration than those fed urea ration occurred as a result of better ability of urea-impregnated zeolite in shifting VFA production pattern from acetate to propionate production as shown in Table 2. Moreover, a negative correlation between acetate and propionate $(\mathrm{P}<0.01, \mathrm{r}=-0.89)$ supported postulate of the shifting of VFA production pattern from acetate toward propionate production in some extend that acetate to propionate ratio became lower in lambs fed urea-impregnated zeolite.

Molar proportion of branch-chained volatile fatty acid (BCVFA) in lambs fed urea-impregnated zeolite ration was higher than those fed urea ration $(\mathrm{P}<0.05)$ but similar to those fed no urea or zeolite ration $(\mathrm{P}>0.05)$. BCVFA proportion value is frequently used as useful index of protein degradation. Since BCVFA proportion consisted of isobutyrate and isovalerate where both were produced from degradation of amino acids valine and leucine, respectively (Van Soest, 1994), it is very possibly that protein degradation still happen in lambs fed no urea, zeolite, or urea-impregnated zeolite ration. In relation to ruminal $\mathrm{pH}$ value, Calsamiglia et al. (2002) demonstrated that branch-chained VFA concentration was higher at ruminal $\mathrm{pH}$ kept constant at 6.4 than that kept constant at 5.7. Present research found ruminal BCVFA proportion had no correlation with $\mathrm{pH}$ value $(\mathrm{P}=0.43)$ but found positive correlation with butyrate $(\mathrm{P}<0.05, \mathrm{r}=$ $0.49)$ or with valerate proportion $(\mathrm{P}<0.01, \mathrm{r}=0.76)$. These findings more likely revealed that BCVFAs that are natu- rally originated from isobutyric and isovaleric acids are utilized by ruminal microbes in an efficient manner that carbon skeletons produced from both isobutyric and isovaleric acids degradation are reutilized to synthesis non-essential amino acids and thus, in turn, the BCVFAs proportion did not influence the ruminal $\mathrm{pH}$ value as previously demonstrated by Calsamiglia et al. (2002).

\section{Ammonia to VFA Ratio}

Similarity of ammonia to VFA ratio across the experimental ration resulted in present research $(\mathrm{P}>0.05)$ indicated that each experimental ration produced similar synchrony between energy and ammonia released from rumen microbial fermentation. Russell et al. (1992) reported that many of the cellulolytic bacteria prefer or require $\mathrm{N}$ in the form of ammonia. It was suggested that cellulolytic microbes became more predominant in the rumen circumstance of animal fed high fiber diets under synchronization between fermentable carbohydrate and ammonia availability such as the ones reflected in the present research. Apparently, ruminal ammonia level resulted in lambs fed urea-impregnated zeolite ration created an optimal condition where synchrony between fermentable carbohydrate and ammonia availability established for growing cellulolytic microbes.

\section{Methane Production}

Estimate methane production ranged from 32.96 to $51.59 \mathrm{mM}$ and fallen within a lower limit of methane production range reported by Puastuti et al. (2012), i.e. 36-70.3 mM. Lower methane production of lambs fed urea-impregnated zeolite ration when compared to those fed urea ration was in association to its lower acetate concentration or to its lower acetate to propionate ratio (Table 2). Lower acetate to propionate ratio in lambs fed urea-impregnated ration indicated that the ration shifted VFAs production pattern from acetate toward propionate production which mean that fermentation process occurred in more efficient manner where more hydrogen ion $\left(\mathrm{H}^{+}\right)$were utilized by ruminal microbes to synthesize propionate rather than to synthesize methane. This finding agreed with Boadi et al. (2004) who reported that reduction in $\mathrm{CH}_{4}$ production can result from a shift in the VFA pattern towards more propionate and less acetate. As a result, methane production became lower in lamb fed urea-impregnated zeolite ration as revealed in the present research.

\section{Plasma Urea Concentrations}

Plasma urea concentrations in the present research varied from 2.16 to $2.75 \mathrm{mM}$ (Figure 1) and its concentrations are influenced by experimental rations $(\mathrm{P}<0.05)$. Lambs fed urea ration produced higher plasma urea concentration when protein nitrogen in no urea ration was substituted with non-protein nitrogen in urea ration $(2.75 \mathrm{mM}$ vs. $2.16 \mathrm{mM}, \mathrm{P}<0.05)$. However, plasma urea concentration of lambs fed zeolite or ureaimpregnated zeolite ration produced similar plasma urea concentration to lambs fed no urea or urea ration 


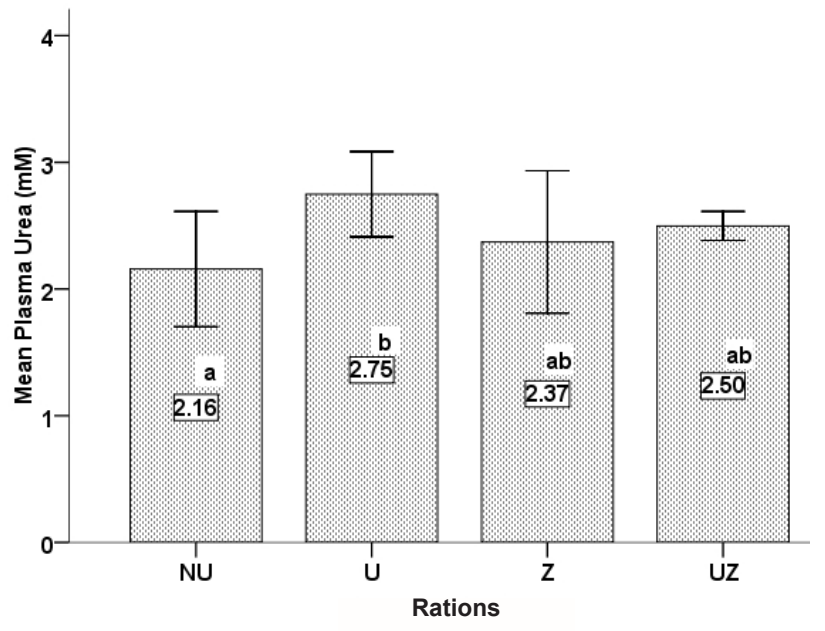

Figure 1. Plasma urea concentrations in lambs fed experimental rations. Different letters within boxplots differ significantly $(\mathrm{P}<0.05)$, error bar $= \pm$ S.D., $N U=$ no urea, $\mathrm{U}=$ urea, $\mathrm{Z}=$ zeolite, $\mathrm{UZ}$ = urea-impregnated zeolite.

$(\mathrm{P}>0.05)$. Higher plasma urea concentration in lambs fed urea ration was in proportion to its higher ruminal ammonia concentration in lambs fed the urea ration (Table 2). This occurrence reflected higher ammonia absorption occurred in lambs fed urea ration and resulted in its higher plasma urea concentration. This finding agreed with Eryavuz et al. (2003) who reported that higher plasma urea concentration was due to high ruminal ammonia as result of rapid hydrolysis of urea to ammonia. Nevertheless, plasma urea concentrations in the present research fall within lower margin of normal physiological range of plasma urea in sheep (2 to $5 \mathrm{mM}$ ) as proposed by Sunny et al. (2007). Efficacy of zeolite or urea-impregnated zeolite in maintaining low plasma urea concentration even its failed to reach significant value when compared to urea or no urea ration, indicated that either zeolite or urea-impregnated zeolite showed slow-release ammonia properties with different mode of action as previously discussed under ruminal ammonia subtitle above, allowed rumen microbes to utilize ruminal ammonia efficiently, and did not impact negatively on post absorptive nitrogen metabolism.

\section{CONCLUSION}

Zeolite or urea-impregnated zeolite as slow-release ammonia or SRU agent was potent in decreasing ruminal ammonia, $\mathrm{pH}$, acetate to propionate ratio, methane, and maintaining low plasma urea within its physiological range.

\section{ACKNOWLEDGEMENT}

The authors would like to thank the Directorate of Research and Community Services, Directorate General of Higher Education, Ministry of Education and Culture, Republic of Indonesia for financial support for the research under National Strategic Research Grant Schemes (No. DIPA 0541/023-04.1.01/00/2012, December 12, 2011).

\section{REFERENCES}

Abdoun, K., F. Stumpff, \& H. Martens. 2007. Ammonia and urea transport across the rumen epithelium: a review. Anim. Health. Res. Rev. 7: 43-59. http://dx.doi.org/10.1017/ S1466252307001156

Abubakar, M., T. A. Adegbola, M. M. Abubakar, Y. Shehu, M. B. Ngele, \& D. J. U. Kalla. 2010. Nutritional evaluation of different sources of nitrogen on digestible nutrient intake, nitrogen balance and production of rumen metabolites in growing Yankasa sheep. Emir. J. Food Agric. 22: 298-307.

Boadi, D., C. Benchaar, J. Chiquette, \& D. Massé. 2004. Mitigation strategies to reduce enteric methane emissions from dairy cows: Update review. Can. J. Anim. Sci. 84: 319-335. http://dx.doi.org/10.4141/A03-109

Broderick, G. A. \& J. H. Kang. 1980. Automated simultaneous determination of ammonia and total amino acids in ruminal fluid and in vitro media. J. Dairy Sci. 63: 64-75. http:// dx.doi.org/10.3168/jds.S0022-0302(80)82888-8

Calsamiglia, S., A. Ferret, \& M. Devant. 2002. Effects of pH and $\mathrm{pH}$ fluctations on microbial fermentation and nutrient flow from a dual-flow continuous culture system. J. Dairy Sci. 85: 574-479. http://dx.doi.org/10.3168/jds.S00220302(02)74111-8

Eryavuz, A., Y. Dündar, M. Ozdemir, R. Aslan, \& M. Tekerli. 2003. Effects of urea and sulfur on performance of faunate and defaunate Ramlic lambs, and some rumen and blood parameters. Anim. Feed Sci. Technol. 109: 35-46. http:// dx.doi.org/10.1016/S0377-8401(03)00201-3

Golombeski, G. L., K. F. Kalscheur, A. R. Hippen, \& Schingoethe. 2006. Slow-release urea and highly fermentable sugars in diets fed to lactating dairy cows. J. Dairy Sci. 89: 4395-4403. http://dx.doi.org/10.3168/jds.S00220302(06)72486-9

Huntington, G. B., D. L. Harmon, N. B. Kristensen, K. C. Hanson, \& J. W. Spears. 2006. Effects of a slow-release urea source on absorption of ammonia and endogenous production of urea by cattle. Anim. Feed Sci. Technol. 130: 225241. http://dx.doi.org/10.1016/j.anifeedsci.2006.01.012

Kardaya, D., K. G. Wiryawan, A. Parakkassi, \& M. Winugroho. 2009. In vitro slow-release urea characteristics under different molasses levels contained in rice straw based diets. JITV 14: 177-191.

Kardaya, D., Supriyati, Suryahadi \& T. Toharmat. 2000. Pengaruh suplementasi $\mathrm{Zn}$-proteinat, $\mathrm{Cu}$-proteinat dan amonium molibdat terhadap performans domba lokal. Med. Pet. 24: 1-9.

Kim, S. C., A. T. Adesogan, \& J. D. Arthington. 2007. Optimizing nitrogen utilization in growing steers fed forage diets supplemented with dried citrus pulp. J. Anim. Sci. 85: 2548-2555. http://dx.doi.org/10.2527/jas.2007-0059

Migliorati, L., F. Abeni, M. P. Cattaneo, C. Tornielli, \& G. Pirlo. 2007. Effects of adsorbent in dairy cow diet on milk quality and cheese-making properties. Ital. J. Anim. Sci. 6 (Suppl. 1): 460-462.

Mlay, P. S., A. E. Pereka, M.R. Weisbjerg, T. Hvelplund, \& J. Madsen. 2003. Digestion and passage kinetics of fibre in mature dairy heifers maintained on poor quality hay as affected by the source and level of nitrogen supplementation. Anim. Feed Sci. Technol. 109: 19-33. http://dx.doi. org/10.1016/S0377-8401(03)00211-6

Mumpton, F. A. 1999. Uses of natural zeolites in agriculture and industry. La roca magica Proc. Natl. Acad. Sci. 96:34633470.

Orskov, E.R. \& M. Ryle. 1990. Energy Nutrition in Ruminant. Elsevier Appl. Sci. London, pp. 24.

Pan, J., T. Suzuki, S. Koike, K. Ueda, \& Y. Kobayashi. 2003. Effect of urea infusion into the rumen on liquid-and particle associated fibrolytic enzyme activities in steers fed 
low quality grass hay. Anim. Feed Sci. Technol. 104: 13-27. http://dx.doi.org/10.1016/S0377-8401(02)00324-3

Puastuti, W. \& I-W. Mathius. 2008. Responses of young rams to level of hydrolised feather meal substitution in ration. JITV 13: 95-102.

Puastuti, W. \& I-W. Mathius. 2012. Ruminal fermentation response and nitrogen retention from sheep fed rumen undegradable protein. JITV 17: 62-72.

Russell, J. B., J. D. O'Connor, D. G. Fox, P. J. Van Soest, \& C. J. Sniffen. 1992. A net carbohydrate and protein system for evaluating cattle diets: I. Ruminal fermentation. J. Anim. Sci. 70: 3551-3561.

Steel, R. G. D. \& J. H. Torrie. 1980. Principles and Procedures of Statistics: A Biometrical Approach. $2^{\text {nd }}$ ed. McGraw-Hill Book Company, New York, New York.

Sunny, N. E., S. L. Owens, R. L. Baldwin VI, S. W. El-Kadi, R. A. Kohn, \& B. J. Bequette. 2007. Salvage of blood urea nitrogen in sheep is highly dependent on plasma urea concentration and the efficiency of capture within the digestive tract. J. Anim. Sci. 85: 1006-1013. http://dx.doi. org/10.2527/jas.2006-548

Syahrir, S., K. G. Wiryawan, A. Parakkasi, M. Winugroho, \& A. Natsir. 2012. Substitution of concentrate with mulberry leaves in Ongole grade cattle fed rice straw base diet. Med. Pet. 35: 123-127. http://dx.doi.org/10.5398/medpet.2012.35.2.123

Taylor-Edwards, C. C., G. Hibbard, S. E. Kitts, K. R. McLeod, D. E. Axe, E. S. Vanzant, N. B. Kristensen, \& D. L. Harmon. 2009. Effects of slow-release urea on ruminal digesta characteristics and growth performance in beef steers. J. Anim. Sci. 87: 200-208. http://dx.doi.org/10.2527/jas.20080912

Van Soest, P. J. 1994. Nutritional Ecology of the Ruminant. 2nd edn. Comstock Publishing Associates, Ithaca, NY, pp. 354-370. 